\title{
New Aphorisms Concerning Science and Scientists
}

\author{
DOI: $10.1134 / \mathrm{S} 1061934810010016$
}

We know many books that collect aphorisms concerning science and scientists (see, for example [1-7]). New ones are also being collected; N.L. Vekshin is among such collectors; some statements from his book [8] are presented below.

Science is a method of solving the world's mysteries by discovering new riddles (A. Davidovich).

Everything brilliant is simple. It is difficult to hit a simple thing (A. Nikitin).

Discussion is an attempt to build one truth from several errors (A. Kruglov).

Nobody believes the hypothesis except for the one who put it forward, but everybody believes the experiment except for the one who has carried it out (Unknown author).

Study is learning rules; experience is studying exceptions (Unknown author).

All exceptions hope to sometimes become rules (I. Gerchikov).

Science is intuition in the service of logic (V. Krotov).

There is no such truism that could not be bashed up once again (Ts. Melamed).

The difference between a scientist and an ignoramus is simple: the first does not know much, but the second knows everything (Ts. Melamed).

In the gutter some see only the pool, and others, looking at the gutter, see stars (Unknown author).

People are born as authors, but become co-authors (I. Gerchikov).

Professionalism is the ability to measure ones own incompetence (A. Mikheev).

Experience is the ability to make mistakes competently (A. Mikheev).

The chief may be interrupted only with applause (A. Davidovich).

Man strongly believing rules will not discover a new rule (V. Borisov).

Having avoided the truth, I felt myself to be Galileo (A. Davidovich).

A decent chief equally divides the merits with those who have done the entire work (Unknown author).

If people cite you, you have already been something. If people steal from you, you are an outstanding person. However, true glory begins only when words of other persons are claimed for you (Unknown author).

An expert is a narrowly focused executive with broad powers (N. Vekshin).

Only those who are under someone's thumb are never mistaken (V. Borisov).

Bends should be straightforward enough so that thoughts are not confused (E. Kascheyev).

I have no megalomania. Great people do not suffer it (S. Yankovskii).

Genius is a person, who is missing something in his head (A. Mikheev).

To achieve much, one has to refuse much (E. Kascheyev).

A workaholic is a person, who at the weekend says to his wife that he is going to work and who really goes to work (N. Vekshin).

\section{REFERENCES}

1. Mysli o nauke (Thoughts on Science), Ponomarev, V.P., Ed., Chisinau: Shtiintsa, 1973. 152 p.

2. Slovo o nauke. Aforizmy. Izrecheniya. Literaturnye tsitaty (Aphorisms, Sentences, and Literature Cites on Science), Likhtenshtein, E.S., Ed., Moscow: Znanie, 1986, 2nd ed. 288 p.

3. Bol'shaya kniga aforizmov (A Large Collection of Aphorisms), Dushenko, K.V., Ed., Moscow: EKSMO, 1999. $1056 \mathrm{p}$.

4. Balyazin, V., Mudrost' tysyacheletii. Entsiklopediya (Wisdom of Millenia: Encyclopedia), Moscow: OLMA, Krasnyi proletarii, 2006. 848 p.

5. Vorontsov, V.V., Simfoniya razuma. Aforizmy i izrecheniya otechestvennykh i zarubezhnykh avtorov (Symphony of Intelligence: Aphorisms and Sentences of Russian and Foreign Authors), Moscow: Molodaya gvardiya, 1977, 2nd ed. $624 \mathrm{p}$.

6. Vekshin, N.L., Mudrost' stoletii. Entsiklopediya aforizmov (Wisdom of Centuries: Encyclopedia of Aphorisms), Moscow: Stoletie, 1997. 450 p.

7. The International Thesaurus of Quotations, Tripp, R.T., Ed., New York: Harper and Row, 1987. 1088 p.

8. Postsovetskie aforizmy (Post-Soviet Aphorisms), Vekshin, N.L., Ed., Pushchino: Foton-vek, 2008. 144 p.

Yu. A. Zolotov 